\title{
Pyrenocines N-0: two novel pyrones from Colletotrichum sp. HCCB03289
}

\author{
Zhijun Yang ${ }^{1}$, LiXia Bao ${ }^{1}$, Yu Yin ${ }^{1}$, Gang Ding ${ }^{2}$, Mei Ge ${ }^{3}$, Daijie Chen ${ }^{1}$ and Xiuping Qian ${ }^{1}$ \\ The Journal of Antibiotics (2014) 67, 791-793; doi:10.1038/ja.2014.59; published online 28 May 2014
}

Pyrenocines are better known as phytotoxic metabolites been found in Alternaria, Curvularia, Penicillium and Phomopsis strains. The class of compounds showed several biological activities, reportedly being phytotoxic, antifungal, cytotoxic, antitrypanosomal and antimalarial. ${ }^{1-3}$ Fungi of the genus Colletotrichum, a class of the widely distributed endophytic fungi, were reported as prolific producers of bioactive metabolites. ${ }^{4-7}$ However, there are few reports on pyrenocines found in genus Colletotrichum. During our ongoing chemical investigations of endophytic fungi as sources of new cytotoxic natural products, the organic solvent extract of solid substrate fermentation culture of a Colletotrichum sp. HCСB03289 strain displayed cytotoxicity against cancer cell lines. Bioassay-guided fractionation of the extract led to the isolation of two novel pyrenocines N-O (1-2), and five known pyrenocines macommelin9 -acetate $(3),{ }^{8}$ pyrenocine A (4), ${ }^{9}$ pyrenocine B (5), ${ }^{9}$ pyrenocine E (6) ${ }^{10}$ and novae-zelandin A (7). ${ }^{11}$ Details of the isolation, structure elucidation and the cytotoxic activities of these compounds are presented here.

The culture of Colletotrichum sp. HCCB03289 was isolated from traditional Chinese medicinal plant Ludwigia prostrata Roxb specimen collected from Tianmu mountain, Zhejiang Province of China, in July 2008. The isolation and identification methods of endophytic fungal strain HCCB03289 were carried out as reported. ${ }^{12}$ The ITS (internal transcribed spacer) sequence data were submitted to GenBank with accession no. KF594420. Its ITS sequence was similar to that of Colletotrichum gloeosporioides strain HGUP0020 (maximal identities: $100 \%$ ), but due to the lack of a sexual structure in the culture, the endophytic fungus was then identified at the genus level only as Colletotrichum sp. The fungal strain was cultured on slants of potato dextrose agar at $28^{\circ} \mathrm{C}$ for 5 days. Then, $5.0 \mathrm{ml}$ of spore suspension (spore/cell $1 \times 10^{6} \mathrm{ml}^{-1}$ ) was inoculated into $500 \mathrm{ml}$ Erlenmeyer flask $(\times 100)$ each with $80 \mathrm{~g}$ of rice medium at $28^{\circ} \mathrm{C}$ for $30 \mathrm{~d}$. The fermented rice substrate was freeze-dried and extracted with ethyl acetate (10 litres) subsequently. The organic solvent was evaporated under vacuum to obtain a crude extract $(20.0 \mathrm{~g}$ ), which was fractionated by silica gel column chromatography $(2.6 \times 40 \mathrm{~cm})$ using petroleum ether/ethyl acetate $(7: 3,6: 4,3: 7,1: 9)$ gradient elution to afford four fractions, Frs. 1-4. The Fr. 1 (1.0 g) was further separated by Sephadex LH-20 (Pharmacia, Uppsala, Sweden) eluted with $\mathrm{CHCl}_{3} / \mathrm{CH}_{3} \mathrm{OH}(10: 1)$ to yield a subfraction of $200 \mathrm{mg}$, which was then purified by semi-prep. RP-HPLC (YMC-Pack RP-C18 column (YMC, Kyoto, Japan), $10 \times 250 \mathrm{~mm}, 65 \% \mathrm{CH}_{3} \mathrm{OH}$ in $\mathrm{H}_{2} \mathrm{O}$ for $\left.40 \mathrm{~min}, 2.5 \mathrm{ml} \mathrm{min}^{-1}\right)$ to yield novae-zelandin A (7, $6.5 \mathrm{mg}$; $t_{\mathrm{R}} 28.3 \mathrm{~min}$ ). The Fr. 2 ( $1.5 \mathrm{~g}$ ) was further separated by Sephadex LH-20 eluted with $\mathrm{CHCl}_{3} / \mathrm{CH}_{3} \mathrm{OH}$ (5:1) to yield a subfraction of $150 \mathrm{mg}$. Purification of the subfraction by semi-prep. RP-HPLC $\left(10 \times 250 \mathrm{~mm}, 45 \% \mathrm{CH}_{3} \mathrm{OH}\right.$ in $\mathrm{H}_{2} \mathrm{O}$ for $\left.30 \mathrm{~min}, 2.5 \mathrm{ml} \mathrm{min}{ }^{-1}\right)$ afforded pyrenocine $\mathrm{E}\left(\mathbf{6}, 11.6 \mathrm{mg} ; t_{\mathrm{R}} 23.5 \mathrm{~min}\right)$. The Fr. $3(1.2 \mathrm{~g})$ was further separated by semi-prep. RP-HPLC (YMC-Pack RP-C18, $20 \times 250 \mathrm{~mm}, 50 \% \mathrm{CH}_{3} \mathrm{OH}$ in $\mathrm{H}_{2} \mathrm{O}$ for $15 \mathrm{~min}$, gradient to $100 \%$ in $30 \mathrm{~min}, 7 \mathrm{ml} \mathrm{min}^{-1}$ ) to afford two subfractions, Frs. 2.1-2.2. The Fr. $2.1(12.3-13.2 \mathrm{~min}, 90 \mathrm{mg})$ was then purified by semi-prep. RP-HPLC $\left(10 \times 250 \mathrm{~mm}, 35 \% \mathrm{MeOH}\right.$ in $\mathrm{H}_{2} \mathrm{O}$ for $\left.30 \mathrm{~min}, 2 \mathrm{ml} \mathrm{min}^{-1}\right)$ to yield pyrenocine B (5, $\left.8.7 \mathrm{mg} ; t_{\mathrm{R}} 14.5 \mathrm{~min}\right)$. The Fr. 2.2 (15.2-16.5 min, $0.12 \mathrm{~g})$ was then purified by semi-prep. RP-HPLC $(10 \times 250 \mathrm{~mm}, 35 \%$ $\mathrm{MeOH}$ in $\mathrm{H}_{2} \mathrm{O}$ for $40 \mathrm{~min}, 2 \mathrm{ml} \mathrm{min}^{-1}$ ) to yield pyrenocine A $\left(4,15.0 \mathrm{mg} ; t_{\mathrm{R}} 31.5 \mathrm{~min}\right)$ and macommelin-9-acetate $\left(3,10.6 \mathrm{mg} ; t_{\mathrm{R}}\right.$ $36.5 \mathrm{~min})$. The Fr. $4(200 \mathrm{mg})$ was purified by semi-prep. RP-HPLC $\left(10 \times 250,20 \% \mathrm{MeOH}\right.$ in $\mathrm{H}_{2} \mathrm{O}$ for $\left.40 \mathrm{~min}, 2 \mathrm{ml} \mathrm{min}^{-1}\right)$ to afford pyrenocine $\mathrm{N}\left(1,12.5 \mathrm{mg} ; t_{\mathrm{R}} 32.1 \mathrm{~min}\right)$ and pyrenocine $\mathrm{O}(2,23.6 \mathrm{mg}$; $\left.t_{\mathrm{R}} 30.6 \mathrm{~min}\right)$. UV data were recorded on a Shimadzu Biospec-1601 spectrometer (Shimadzu, Kyoto, Japan). IR data were recorded using a Nicolet 6700 FT-IR spectrometer (Thermo-Fisher, Madison, WI, USA) with $\mathrm{KBr}$ disks. Optical rotations were measured by JASCO P-2000 spectropolarimeter (Jasco, Tokyo, Japan). ${ }^{1} \mathrm{H}$ and ${ }^{13} \mathrm{C}$ NMR data were acquired with a Bruker Avance-500 (Bruker, Fällanden, Zurich, Switzerland) and Bruker Avance-400 spectrometer using solvent signals $\left(\mathrm{CDCl}_{3} ; \delta_{\mathrm{H}} \quad 7.26 / \delta_{\mathrm{C}} \quad 77.6\right.$, $\left.\mathrm{CD}_{3} \mathrm{OD} ; \delta_{\mathrm{H}} 3.31 / \delta_{\mathrm{C}} \quad 49.0\right)$ as references. HRESIMS data were acquired using a Waters QTOFMS Premier spectrometer (Waters, Milford, MA, USA).

Pyrenocine N (1) was obtained as yellow oil. The molecular formula $\mathrm{C}_{10} \mathrm{H}_{12} \mathrm{O}_{4}$ was determined by positive HR-ESI-MS at $\mathrm{m} / \mathrm{z}$ 197.0808 $[\mathrm{M}+\mathrm{H}]^{+}$requiring five degrees of instaurations. The IR

1School of Pharmacy, Shanghai Jiaotong University, Shangai, China; ${ }^{2}$ Institute of Medicinal Plant Development, Beijing, China and ${ }^{3}$ Shanghai Laiyi Center for Biopharmaceutical R\&D, Shanghai, China

Correspondence: Dr X Qian, School of Pharmacy, Shanghai Jiaotong University, 800 Dongchuan Road, Shanghai 200240, China.

E-mail: Qianxp@sjtu.edu.cn

Received 29 December 2013; revised 18 March 2014; accepted 14 April 2014; published online 28 May 2014 
spectrum suggested the presence of hydroxyl group $\left(3405 \mathrm{~cm}^{-1}\right)$ and carbonyl group $\left(1700 \mathrm{~cm}^{-1}\right)$. The ${ }^{1} \mathrm{H},{ }^{13} \mathrm{C}$ and HSQC spectra of 1 revealed the presence of two methyl groups, one methylene unit, two oxygenated methines, four olefinic carbons and one carboxyl carbon. These data (Table 1 and Supplementary Fig. S1-S5) accounted for all ${ }^{1} \mathrm{H}$ and ${ }^{13} \mathrm{C}$ resonances except one exchangeable proton and suggested 1 contained two rings. The presence of the C-4 oxygenated pyrone moiety was evident from $\delta_{\mathrm{H}} 5.36(\mathrm{~s}, \mathrm{H}-5)$ in the ${ }^{1} \mathrm{H}$ NMR spectrum, and $\delta_{\mathrm{C}} 176.0$ (C-4), 168.5 (C-6), 157.3 (C-2), 113.4 (C-3) and 85.0 (C-5) in the ${ }^{13} \mathrm{C}$ NMR spectrum. ${ }^{13}$ Analysis of the ${ }^{1} \mathrm{H},{ }^{1} \mathrm{H}-\mathrm{COSY}$ NMR data led to the identification of one isolated ${ }^{1} \mathrm{H}$ spin-system corresponding to the $\mathrm{C}-7$ to $\mathrm{C}-10$ subunit of structure 1 . HMBCs (Figure 1) of $\mathrm{H}_{2}-7$ to $\mathrm{C}-2, \mathrm{C}-3$ and $\mathrm{C}-4$ and of $\mathrm{H}-8$ with $\mathrm{C}-4$ permitted completion of the dihydrofuran subunit. Correlations from $\mathrm{H}_{3}-11$ to $\mathrm{C}-2$ and $\mathrm{C}-3$ indicated the connection of $\mathrm{C}-11$ to $\mathrm{C}-2$. The remaining hydroxyl could be located at C-9 corresponding the ${ }^{13} \mathrm{C}$ NMR chemical shift 68.6. On the basis of these data, the gross structure of 1 was characterized (Figure 2).

Pyrenocine $\mathrm{O}(2)$ was obtained as yellow oil, which assigned the same molecular formula $\mathrm{C}_{10} \mathrm{H}_{12} \mathrm{O}_{4}$ as pyrenocine $\mathrm{N}(\mathbf{1})$ by positive HR-ESI-MS at $m / z 197.0812[\mathrm{M}+\mathrm{H}]^{+}$. Analysis of the ${ }^{1} \mathrm{H}$ and ${ }^{13} \mathrm{C}$ NMR data (Table 1 and Supplementary Fig. S9-S13) for 2 revealed the presence of nearly identical structural features to those found in 1, except that the chemical shifts for the two oxymethines C-8 $\left(\delta_{\mathrm{H}} / \delta_{\mathrm{C}} 4.78 / 92.4\right.$ in $1 ; 4.75 / 92.3$ in 2$)$ and C-9 $\left(\delta_{\mathrm{H}} / \delta_{\mathrm{C}} 4.12 / 68.6\right.$ in 1 ; 3.86-3.90/69.6 in 2), as well as the ${ }^{1} \mathrm{H}-{ }^{1} \mathrm{H}$ coupling constant

Table $1{ }^{1} \mathrm{H}\left(500 \mathrm{MHz}, \mathrm{CDCl}_{3}\right)$ and ${ }^{13} \mathrm{C}$ NMR (100MHz, $\left.\mathrm{CD}_{3} \mathrm{OD}\right)$ spectra data of 1 and 2 ( $\delta$ in p.p.m., $J$ in $\mathrm{Hz}$ )

\begin{tabular}{lcccc}
\hline & \multicolumn{1}{c}{$\mathbf{2}$} & \\
Position & $\delta_{H}$ & $\delta_{C}$ & $\delta_{H}$ & $\delta_{C}$ \\
\hline 2 & & 157.3 & & 157.2 \\
3 & & 113.4 & & 113.4 \\
4 & & 176.0 & & 176.1 \\
5 & $5.36(\mathrm{~s}, 1 \mathrm{H})$ & 85.0 & $5.44(\mathrm{~s}, 1 \mathrm{H})$ & 85.2 \\
6 & & 168.5 & & 168.6 \\
$7 \alpha$ & $2.99(\mathrm{dd}, 15.1,6.0,1 \mathrm{H})$ & 25.0 & $3.00(\mathrm{dd}, 15.2,8.8,1 \mathrm{H})$ & 27.0 \\
$7 \beta$ & $2.87(\mathrm{dd}, 15.3,8.9,1 \mathrm{H})$ & & $2.84(\mathrm{dd}, 15.3,6.6,1 \mathrm{H})$ & \\
8 & $4.78(\mathrm{ddd}, 9.0,6.5,3.5$, & 92.4 & $4.75(\mathrm{ddd}, 8.7,6.7,5.3$, & 92.3 \\
& $1 \mathrm{H})$ & & $1 \mathrm{H})$ & \\
9 & $4.12(\mathrm{qd}, 6.5,3.9,1 \mathrm{H})$ & 68.6 & $3.86-3.90(\mathrm{~m}, 1 \mathrm{H})$ & 69.6 \\
10 & $1.20(\mathrm{~d}, 6.5,3 \mathrm{H})$ & 18.5 & $1.32(\mathrm{~d}, 6.5,3 \mathrm{H})$ & 18.9 \\
11 & $2.16(\mathrm{~s}, 3 \mathrm{H})$ & 17.6 & $2.19(\mathrm{~s}, 3 \mathrm{H})$ & 17.6 \\
\hline
\end{tabular}

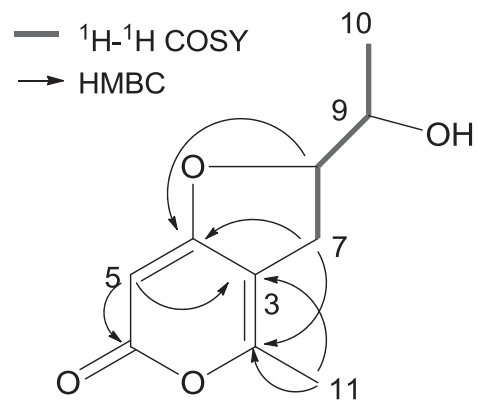

Figure $1^{1} \mathrm{H}^{1} \mathrm{H}$ COSY and key HMBCs of 1 . A full color version of this figure is available at The Journal of Antibiotics journal online. observed between $\mathrm{H}-8$ and $\mathrm{H}-9$ were different. These data implied that $\mathbf{2}$ was a stereoisomer of $\mathbf{1}$, and this conclusion was supported by analysis of its COSY and HMBC data.

The relative configuration of compounds $\mathbf{1}$ and 2 was assigned by NOED data (Supplementary Fig. S6). Upon irradiation of $\mathrm{H}_{3}-10$, enhancement was observed for $\mathrm{H}-8$ in the NOE difference spectrum of 1, suggesting a cis relationship between $\mathrm{H}_{3}-10$ and $\mathrm{H}-8$, whereas enhancement was not observed for $\mathrm{H}-8$ in the spectrum of $\mathbf{2}$, indicating a trans relationship between $\mathrm{H}_{3}-10$ and $\mathrm{H}-8$.

The absolute configuration of pyrenocine $\mathrm{N}(1)$ was assigned by application of the modified Mosher method. ${ }^{14,15}$ Treatment of 1 with $(S)$-MTPA Cl and (R)-MTPA Cl afforded the R-MTPA ester (1a) and $S$-MTPA ester (1b), respectively. The difference in chemical shift values $\left(\Delta \delta=\delta_{\mathrm{S}}-\delta_{\mathrm{R}}\right)$ for the diastereomeric esters $\mathbf{1} \mathbf{b}$ and $\mathbf{1 a}$ were calculated in order to assign the absolute configuration at C-9 (Figure 3 and Supplementary Fig. S7,S8).

Negative $\Delta \delta$ values were observed for $\mathrm{H}-10(-0.08)$ and $\mathrm{H}-8$ $(-0.03)$, while positive $\Delta \delta$ values were observed for $\mathrm{H} \alpha-7(+0.08)$, $\mathrm{H} \beta-7(+0.07), \mathrm{H}-5(+0.02)$ and $\mathrm{H}-11(+0.01)$, indicating the $R$ absolute configuration at C-9 (Figure 2). Accordingly the configurations at C-8 and C- 9 were assigned as $8 S$ and $9 R$ for 1 . Therefore, the absolute configuration of 2 was deduced as $8 S$ and $9 S$.

Pyrenocine N (1): Yellow oils. $[\alpha]_{D}^{22}=+28.2\left(c 0.7, \mathrm{CH}_{3} \mathrm{OH}\right)$. UV $\left(\mathrm{CH}_{3} \mathrm{OH}\right): 238$ ( $\left.\log \varepsilon 2.43\right), 285$ (log $\left.\varepsilon 3.66\right)$. IR (neat) $v_{\max } 3405$ (br), $2975,2925,1700,1656,1602,1440,1272,1222 \mathrm{~cm}^{-1} .{ }^{1} \mathrm{H}-$ and ${ }^{13} \mathrm{C}-$ NMR: see Table 1. HRESI-MS (positive) $\mathrm{m} / z: 197.0808\left([\mathrm{M}+\mathrm{H}]^{+}\right.$, $\mathrm{C}_{10} \mathrm{H}_{13} \mathrm{O}_{4}^{+}$; calcd 197.0814).

Pyrenocine $\mathrm{O}$ (2): Yellow oils. $[\alpha]_{D}^{22}=+63.0$ (c $\left.0.20, \mathrm{CH}_{3} \mathrm{OH}\right)$. $\mathrm{UV}\left(\mathrm{CH}_{3} \mathrm{OH}\right): 238$ (log $\left.\varepsilon 2.17\right), 285$ (log $\varepsilon$ 3.40). IR (neat) $v_{\max } 3423$

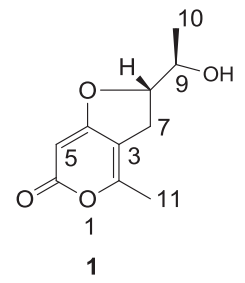<smiles>Cc1oc(=O)cc2c1C[C@H](C(C)O)O2</smiles><smiles>COc1cc(=O)oc(C)c1CCOC(C)=O</smiles><smiles>C/C=C/C(=O)c1c(OC)cc(=O)oc1C</smiles><smiles>[R7]C(C)CC(=O)c1c(OC)cc(=O)oc1C</smiles><smiles>C/C=C/Cc1c(OC)cc(=O)oc1C</smiles>

Figure 2 Structures of compounds of 1-7.

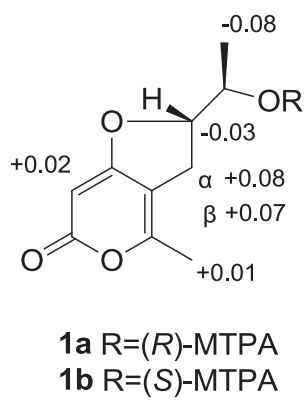

Figure $3 \Delta \delta S-R$ values of MTPA esters of 1 . 
Table 2 Cytotoxic activities of compounds 1-7

\begin{tabular}{lccc}
\hline & \multicolumn{3}{c}{ Cytotoxicity, $C_{50}\left(\mu \mathrm{gm} \mathrm{I}^{-1}\right)$} \\
\cline { 2 - 4 } Compound & A549 & MDA-MB-231 & PANC-1 \\
\hline $\mathbf{1}$ & $>500$ & $>500$ & $>500$ \\
$\mathbf{2}$ & $>500$ & $>500$ & $>500$ \\
$\mathbf{3}$ & $>500$ & $>500$ & $>500$ \\
$\mathbf{4}$ & 1.2 & 3.9 & 3.2 \\
$\mathbf{5}$ & 7.2 & 25.8 & 14.1 \\
$\mathbf{6}$ & 15.6 & 26.3 & 19.1 \\
$\mathbf{7}$ & 175.6 & 373.2 & 150.0 \\
$5-$ Fluorouracil & 75 & 47 & 65 \\
\hline
\end{tabular}

(br), 2977, 2929, 1706, 1602, 1434, $1216 \mathrm{~cm}^{-1} \cdot{ }^{1} \mathrm{H}$ - and ${ }^{13} \mathrm{C}-\mathrm{NMR}$ : see Table 1. HRESI-MS (positive) $\mathrm{m} / z$ : $197.0812\left([\mathrm{M}+\mathrm{H}]^{+}, \mathrm{C}_{10} \mathrm{H}_{13} \mathrm{O}_{4}^{+}\right.$; calcd 197.0814).

Compounds 1-7 were evaluated for cytotoxic activities against three human cancer cell lines: A549, MDA-MB-231 and PANC-1 in vitro using the MTT method (Table 2). Compound 4 showed most potent antitumor activities with $\mathrm{CC}_{50}$ values less than $4.0 \mu \mathrm{g} \mathrm{ml}^{-1}$ against cancer cell lines, which was stronger than that of 5fluorouracil (the positive control). Compounds 5-6 displayed significant cytotoxicity, whereas compounds 1-3 have no cytotoxic activities. Based on the analysis of cytotoxicity potencies and the structural characteristics of 4-6 and 1-3 or 7, it was found that 3ketone group in branched chain (4-6) would significantly increase the cytotoxic activities. Moreover, $\alpha$-, $\beta$-unsaturated ketone in branched chain of compound 4 could further strengthen cytotoxicity than that of 5 or 6.

\section{ACKNOWLEDGEMENTS}

This work was supported by the National S\&T Major Special Project on Major New Drug Innovation (2012ZX09301002-003(-007)).

1 Hussain, H. et al. Pyrenocines J-M: four new pyrenocines from the endophytic fungus, Phomopsis sp. Fitoterapia 83, 523-526 (2012).

2 Hussain, $H$. et al. Phomopsinones A-D: four new pyrenocines from endophytic fungus Phomopsis sp. Eur. J. Org. Chem 9, 1783-1789 (2012).

3 Hashida, J. et al. Pyrenocine I, a new pyrenocine analog produced by Paecilomyces sp. FKI-3573. J. Antibiot. 63, 559-561 (2010).

4 Otsuka, T. et al. WF14861, a new cathepsins B and L inhibitor produced by Colletotrichum sp. II. Biological properties. J. Antibiot. 52, 542-547 (1999).

5 Ren, Y. et al. Colutellin A, an immunosuppressive peptide from Colletotrichum dematium. Microbiology 154, 1973-1979 (2008).

6 Wicklow, D. T., Jordan, A. M. \& Gloer, J. B. Antifungal metabolites (monorden, monocillins I, II, III) from Colletotrichum graminicola, a systemic vascular pathogen of maize. Mycol. Res. 113, 1433-1442 (2009).

7 Tianpanich, K. et al. Radical scavenging and antioxidant activities of isocoumarins and a phthalide from the endophytic fungus Colletotrichum sp. J. Nat. Prod. 74, 79-81 (2011).

8 Shimizu, S., Sakurai, I. \& Yamamoto, Y. Isolation and structure of macommelins, novel metabolites of Macrophoma commelinae. Chem. Pharm. Bull. 31, 3781-3784 (1983).

9 Ichihara, A., Murakami, K. \& Sakamura, S. Synthesis of pyrenocines A, B and pyrenochaetic acid A. Tetrahedron 43, 5245-5250 (1987).

10 Takahashi, C. et al. Cytotoxic metabolites from a fungal adherent of a marine alga. Phytochemistry 38, 155-158 (1995).

11 Christensen, K. B. et al. Novel chemotaxonomic markers of the Alternaria infectoria species-group. J. Agric. Food. Chem. 53, 9431-9435 (2005).

12 Yang, Z. J. et al. A novel phytotoxic nonenolide from Phomopsis sp. HCCB03520. Chem. Biodivers. 9, 403-408 (2012).

13 Abrell, L. M., Cheng, X. C. \& Crews, P. New nectriapyrones by salt water culture of a fungus separated from an Indo-Pacific sponge. Tetrahedron Lett. 35, 9159-9160 (1994).

14 Dale, J. A. \& Mosher, H. S. Nuclear magnetic resonance enantiomer regents. Configurational correlations via nuclear magnetic resonance chemical shifts of diastereomeric mandelate, 0-methylmandelate, and.alpha.-methoxy-.alpha.-trifluoromethylphenylacetate (MTPA) esters. J. Am. Chem. Soc. 95, 512-519 (1973).

15 Ohtani, I., Kusumi, T., Kashman, Y. \& Kakisawa, H. High-field FT NMR application of Mosher's method. The absolute configurations of marine terpenoids. J. Am. Chem. Soc. 113, 4092-4096 (1991).

Supplementary Information accompanies the paper on The Journal of Antibiotics website (http://www.nature.com/ja) 